\author{
Alicja Grześkowiak \\ Wrocław University of Economics \\ Faculty of Management, Information Systems and Finance \\ e-mail: alicja.grzeskowiak@ue.wroc.pl
}

\title{
Kompetencje a zachowania edukacyjne dorosłych Polaków*
}

\section{Competences and Educational Behaviours of Adult Poles}

Increasing activity in the field of lifelong learning is an important educational goal of the European Union. The rapidly changing environment creating new demands makes it necessary to take action in the field of continuous education. Labour market requirements in the process of evolving towards a knowledge-based society are changing, which is particularly important in the era of population ageing and raising the retirement age. All forms of education: formal, non-formal and informal should gain importance in response to the growing requirements. The situation in Poland is vary unfavourable when comparing the participation in activities related to lifelong learning with other European Union countries. Research indicates various demographic, social and economic determinants of adult engagement in lifelong learning. This study attempts to assess the relationships between the level of competences in various areas and the educational behaviours of adult Poles. The analyses are based on individual data from a national survey on human capital. The crucial purpose, which is to identify interdependences among the considered factors, attitudes and behaviours, is accomplished by selected statistical and econometric methods supported by suitable data visualization techniques.

Keywords: lifelong learning, educational strategies, statistical analysis

JEL Classification: J24, M53

\footnotetext{
* Artykuł opublikowany w ramach projektu „Popularyzacja najnowszej wiedzy ekonomicznej wśród ludzi młodych" realizowanego z Narodowym Bankiem Polskim w ramach programu edukacji ekonomicznej.

Praca naukowa sfinansowana ze środków Narodowego Centrum Nauki w ramach projektu badawczego 2012/05/B/HS4/02499.
} 


\section{Wprowadzenie}

Zwiększanie uczestnictwa dorosłych w procesie uczenia się przez całe życie jest jednym z ważnych celów edukacyjnych Unii Europejskiej. Według danych Eurostatu w 2014 r. Polska zajmowała w tym obszarze dwudziestą drugą lokatę wśród krajów Unii Europejskiej z odsetkiem osób w wieku 25-64 podejmujących kształcenie w ciągu czterech tygodni poprzedzających ankietę na poziomie $4 \%$, podczas gdy średnia dla UE-28 wynosiła $10,7 \%$. Najnowsze badania dotyczące tej problematyki ${ }^{1}$ wskazują, że na uczestnictwo dorosłych Polaków w kształceniu mają wpływ różne czynniki o charakterze demograficznym, społecznym i ekonomicznym, takie jak: płeć, wiek, miejsce zamieszkania, wykształcenie, posiadanie dzieci, stan zdrowia, status na rynku pracy, cechy miejsca pracy, czy dochody. Niniejszy artykuł przyjmuje inną perspektywę stanowiąc próbę oceny powiązań pomiędzy poziomem różnych kompetencji a zachowaniami edukacyjnymi.

Zasadniczym celem artykułu jest identyfikacja współwystępowania badanych czynników-kompetencji oraz postaw i zachowań edukacyjnych. Postawiono cztery hipotezy badawcze:

(1) H1: Istnieją zależności pomiędzy poziomem kompetencji a zachowaniami edukacyjnymi.

(2) H2: Istnieją zestawy czynników-kompetencji, które są w znacznym stopniu powiązane z postawami edukacyjnymi.

(3) H3: Osoby o niskim poziomie kompetencji są zainteresowane ich rozwijaniem, wobec czego decydują się na uczestnictwo w kształceniu.

(4) H4: Osoby o wysokim poziomie kompetencji są świadome wartości, jakie niesie ich posiadanie, i dążą do dalszego ich podnoszenia.

Cel artykułu jest realizowany $\mathrm{z}$ wykorzystaniem wybranych metod statystyczno-ekonometrycznych. Wyniki analiz prezentowane są z zastosowaniem technik wizualizacji danych, które w syntetyczny i przejrzysty sposób umożliwiają prezentację rezultatów.

\section{Dane i metody badawcze}

W analizie wykorzystano dane pochodzące z ogólnopolskiego badania pt. Bilans Kapitału Ludzkiego, z części poświęconej ludności w wieku produkcyjnym ( $\mathrm{N}=17$ 600), z edycji mającej miejsce w 2013 r. Baza danych zawiera zarówno samoocenę kompetencji, jak i odpowiedzi na pytania pozwalające zidentyfikować zachowania edukacyjne danej osoby.

\footnotetext{
${ }^{1}$ Kompetencje Polaków a potrzeby polskiej gospodarki, Raport podsumowujący IV edycję badań BKL z 2013 r., red. J. Górniak, Polska Agencja Rozwoju Przedsiębiorczości, Warszawa 2014, s. 77-130; Uwarunkowania decyzji edukacyjnych, red. M. Rószkiewicz, K. Saczuk, Instytut Badań Edukacyjnych, Warszawa 2014, s. 94-127; A. Grześkowiak, Statystyczna analiza aktywności edukacyjnej osób dorostych $w$ Polsce, „Ekonometria” 2013, 2(40), s. 29-33; P. Strzelecki, K. Saczuk, I. Grabowska, I.E. Kotowska Rynek pracy [w:] Diagnoza Społeczna 2013. Warunki i jakość życia Polaków, red. J. Czapiński, T. Panek, „Contemporary Economics” 2013, vol. 7, Special Issue, s. 144-152.
} 
W zakresie kompetencji w badaniu uwzględniono różne elementy ujęte w dwanaście głównych rodzajów ${ }^{2}$ : wyszukiwanie i analiza informacji oraz wyciąganie wniosków; obsługa, montowanie i naprawa urządzeń technicznych; wykonywanie obliczeń; obsługa komputera i wykorzystanie Internetu; zdolności artystyczne i twórcze; sprawność fizyczna; samoorganizacja pracy i przejawianie inicjatywy; kontakty z innymi ludźmi, zarówno ze współpracownikami, jak i klientami czy podopiecznymi; organizowanie i prowadzenie prac biurowych; zdolności kierownicze i organizacja pracy innych; dyspozycyjność; biegłe posługiwanie się językiem polskim w mowie i piśmie.

Respondenci dokonywali samooceny poziomu wymienionych kompetencji w pięciopunktowej skali porządkowej, określonej następująco: 1 - niski, 2 - podstawowy, 3 - średni, 4 - wysoki, 5 - bardzo wysoki. Ze względu na długi opis poszczególnych kompetencji na rysunkach i w tabeli zastosowano notację skróconą, odpowiednio: Analiza, Maszyny, Obliczenia, Komputer, Twórcze, Sprawność, Inicjatywa, Komunikacja, Biuro, Kierowanie, Dyspozycyjność, Polski.

$\mathrm{Z}$ kolei w zakresie postaw edukacyjnych posłużono się odpowiedziami na pytania o dotychczasowe uczestnictwo $\mathrm{w}$ różnych formach kształcenia oraz plany w tym obszarze na najbliższy rok.

Wszystkie rozpatrywane zmienne mają charakter niemetryczny, co warunkuje wybór metod badawczych. Analizy relacji pomiędzy deklarowanymi umiejętnościami a gotowością do podejmowania kształcenia przeprowadzono wykorzystując metody statystyczne o zróżnicowanym stopniu złożoności. Do oceny zależności pomiędzy parami cech typu: dana kompetencja - dana strategia edukacyjna wykorzystano klasyczne podejście bazujące na teście chi-kwadrat oraz współczynniku V-Cramera. Takie postępowanie niesie wprawdzie określone informacje, ale nie uwzględnia interakcji pomiędzy zmiennymi. Tymczasem samoocena kompetencji dokonywana przez respondentów ma charakter wielowymiarowy, dlatego też w dalszej części pracy zastosowano metodę umożliwiającą łączne ujęcie wielu zmiennych. Brane pod uwagę dane dotyczące kompetencji liczą dwanaście wymiarów, co znacznie komplikuje analizę w przypadku rozpatrywania ich w surowej formie. Dlatego też wykorzystano technikę redukcji wielowymiarowości - analizę głównych składowych, czyli transformację danych pierwotnych w nowe, określone w przestrzeni o niższym wymiarze. Zmniejszenie wymiaru pozwala na zastosowanie technik wizualizacyjnych i ułatwia wykrycie istniejących prawidłowości.

Analiza głównych składowych zasadza się na konstrukcji nowych zmiennych będących liniowymi kombinacjami zmiennych pierwotnych. Współczynniki wyznacza się tak, by pierwsza składowa miała maksymalną wariancję, druga składowa maksymalizowała pozostałą część wariancji i była nieskorelowana z pierwszą, a kolejne składowe określane są analogicznie. Jeżeli kilka pierwszych składowych reprezentuje dostatecznie dużą część wariancji, to bierze się je pod uwagę, a pozostałe

\footnotetext{
2 Bilans kapitału ludzkiego w Polsce. Badania ludności, 2013, s. 18-19, http://bkl.parp.gov.pl/system/files/Downloads/20140527101857/BKL_ludnosc_2013.pdf?1401179482 (data dostępu: 05.07.2015).
} 
składowe pomija. Wyczerpujący opis procedury można znaleźć np. w pracach Duntemana, Jolliffe i Stanisza ${ }^{3}$. Warto podkreślić, że stosowanie metody do celów opisowych nie wymaga spełnienia założenia o normalności rozkładu zmiennych ${ }^{4}$. W zasadzie metodę w wersji klasycznej stosuje się do zmiennych zmierzonych na mocnych skalach pomiaru, ale dopuszcza się również jej stosowanie w przypadku skal porządkowych ${ }^{5}$. Jeżeli do opisu wystarczają dwie lub trzy składowe, to rezultaty analizy można w atrakcyjny sposób przedstawić za pomocą wykresu typu biplot wprowadzonego przez Gabriela ${ }^{6}$, niosącego wiele informacji o zmiennych i obiektach oraz ich wzajemnych relacjach. Zasadnicze elementy tego rodzaju wizualizacji przedstawiają się następująco ${ }^{7}$ :

(1) zmienne są wyrażane za pomocą wektorów,

(2) obiekty są przedstawiane za pomocą punktów,

(3) środek układu współrzędnych odpowiada średnim wartościom cech,

(4) położenie wektorów względem siebie odzwierciedla zależności pomiędzy zmiennymi,

(5) położenie punktów względem siebie ukazuje stopień podobieństwa obiektów,

(6) położenie punktów względem wektorów niesie informację o wartościach zmiennych w obiektach.

Zaprezentowanie konfiguracji obiektów i cech w przestrzeni o niskim wymiarze pozwala na wgląd w strukturę zbioru.

\section{Kompetencje a strategie edukacyjne}

Problematykę uczestnictwa w procesie uczenia się przez całe życie można analizować w kontekście przeszłości, tj. czy aktywność tego rodzaju miała miejsce, oraz w sensie planów na przyszłość, tj. czy planowane jest podejmowanie kształcenia. Kombinacja odpowiedzi na pytania o przeszłość i przyszłość pozwala wyróżnić cztery strategie edukacyjne ${ }^{8}$ :

(1) aktywność edukacyjną, czyli uczestniczenie w edukacji w dowolnej formie i deklarowanie chęci dalszego uczenia się,

(2) bierność edukacyjną - brak uczestnictwa w jakiejkolwiek formie edukacji i brak w tym zakresie planów na przyszłość,

\footnotetext{
${ }^{3}$ G.H. Dunteman, Principal Components Analysis, Sage Publications, Newbury Park CA 1989; I. Jolliffe Principal Component Analysis, Springer, New York 2002; A. Stanisz, Przystępny kurs statystyki z zastosowaniem STATISTICA PL na przykładach z medycyny, StatSoft, Kraków 2007, s. 165-181.

${ }^{4}$ Ibidem, s. 180.

${ }^{5}$ J. Górniak, My i nasze pieniądze. Studium postaw wobec pieniądza, Wydawnictwo Aureus, Kraków 2000, s. 312-313.

${ }^{6}$ K.R. Gabriel, The Biplot Graphic Display of Matrices with Application to Principal Component Analysis, „Biometrica” 1971, nr 58 (3), s. 453-467.

${ }^{7}$ A. Sagan, Jeden obraz ukazuje więcej niż 10 liczb, czyli jak budować mapy zadowolenia klienta z wykorzystaniem programu STATISTICA, StatSoft, Kraków 2004, s. 39-41; A. Stanisz, op. cit., s. 194-196; P.M. Kroonenberg, Applied Multiway Data Analysis, John Wiley \& Sons, Hoboken 2008, s. 497-498.

${ }^{8}$ Kompetencje Polaków a potrzeby..., s. 106-107.
} 
(3) niekontynuowanie aktywności edukacyjnej rozumiane jako uczestniczenie w edukacji w dowolnej formie i brak deklaracji dalszego uczenia się,

(4) planowanie w przyszłości - brak uczestnictwa w jakiejkolwiek formie edukacji i deklarowanie chęci dalszego uczenia się.

$\mathrm{W}$ badaniu pt. Bilans kapitatu ludzkiego przyjęto dwunastomiesięczne ramy czasowe zarówno w kontekście działań w przeszłości, jak i planów na przyszłość.

Badanie powiązań pomiędzy przyjmowaną strategią edukacyjną a deklarowanym poziomem kompetencji rozpoczęto od podejścia eksploracyjnego bazującego na próbie wychwycenia prawidłowości w oparciu o wykresy obrazkowe. $\mathrm{Na}$ rys. 1 przedstawiono rozkłady deklarowanego poziomu kompetencji z podziałem na cztery strategie edukacyjne. Wyraźnie zaznacza się duży odsetek odpowiedzi o bardzo wysokim poziomie kompetencji (ocena 5) w grupie aktywnych edukacyjnie. Przedstawiciele tej kategorii rzadko oceniają słabo swoje umiejętności (odpowiedzi 1 i 2). Odwrotną prawidłowość można zauważyć w grupie biernych edukacyjnie. Osoby, które się nie dokształcały i nie zamierzają uczyć, oceniają swoje kompetencje zdecydowanie gorzej - odpowiedzi z górnego końca skali (5) pojawiają się zdecydowanie rzadziej niż w pozostałych grupach, natomiast częściej występują oceny słabe ( 1 i 2 ). Rys. 1 uwidacznia zasadnicze różnice w poziomie kompetencji respondentów charakteryzujących się postawą aktywną, bierną i pozostałymi strategiami, ale nie pozwala na ocenę siły zależności i nie umożliwia dokonania całościowych porównań. $Z$ tego względu w dalszej części zastosowano metody pozwalające na bardziej szczegółową analizę współwystępowania rozpatrywanych cech.

Do oceny powiązań poziomu poszczególnych kompetencji i przyjmowanych strategii edukacyjnych zastosowano test niezależności chi-kwadrat oraz współczynnik V-Cramera (tab. 1).

Dla wszystkich analizowanych kompetencji test chi-kwadrat wskazuje na odrzucenie hipotezy o braku zależności i przyjęcie hipotezy o występowaniu związku pomiędzy poziomem kompetencji a przyjmowaną strategią edukacyjną. Ze względu na fakt, że wartość statystyki chi-kwadrat jest uzależniona od wielkości próby, nie nadaje się ona bezpośrednio do oceny siły związku. Tego rodzaju wady jest pozbawiony współczynnik V-Cramera unormowany w przedziale $\langle 0 ; 1\rangle$, co pozwala oceniać siłę zależności i dokonywać porównań. Wartości współczynników V-Cramera wskazują, że zależność pomiędzy poziomem kompetencji a strategią edukacyjną istnieje, ale nie ma bardzo dużego natężenia. Najsilniejszy związek występuje w przypadku umiejętności informatycznych, w zakresie biegłego posługiwania się językiem polskim, organizowania pracy i przejmowania inicjatywy oraz kompetencji analitycznych. Najsłabsze powiązania dotyczą obsługiwania maszyn i działań twórczych.

Dla wszystkich analizowanych kompetencji test chi-kwadrat wskazuje na odrzucenie hipotezy o braku zależności i przyjęcie hipotezy o występowaniu związku pomiędzy poziomem kompetencji a przyjmowaną strategią edukacyjną. Ze względu na fakt, że wartość statystyki chi-kwadrat jest uzależniona od wielkości próby, nie nadaje się ona bezpośrednio do oceny siły związku. Tego rodzaju wady jest pozbawiony współczynnik $\mathrm{V}$-Cramera unormowany w przedziale $<0 ; 1>$, co pozwala 
oceniać siłę zależności i dokonywać porównań. Wartości współczynników V-Cramera wskazują, że zależność pomiędzy poziomem kompetencji a strategią edukacyjną istnieje, ale nie ma bardzo dużego natężenia. Najsilniejszy związek występuje w przypadku umiejętności informatycznych, w zakresie biegłego posługiwania się językiem polskim, organizowania pracy i przejmowania inicjatywy oraz kompetencji analitycznych. Najsłabsze powiązania dotyczą obsługiwania maszyn i działań twórczych.

Rys. 1. Rozkłady poziomu kompetencji w skali 1-5 w odniesieniu do strategii edukacyjnych

\section{Strategia edukacyjna}

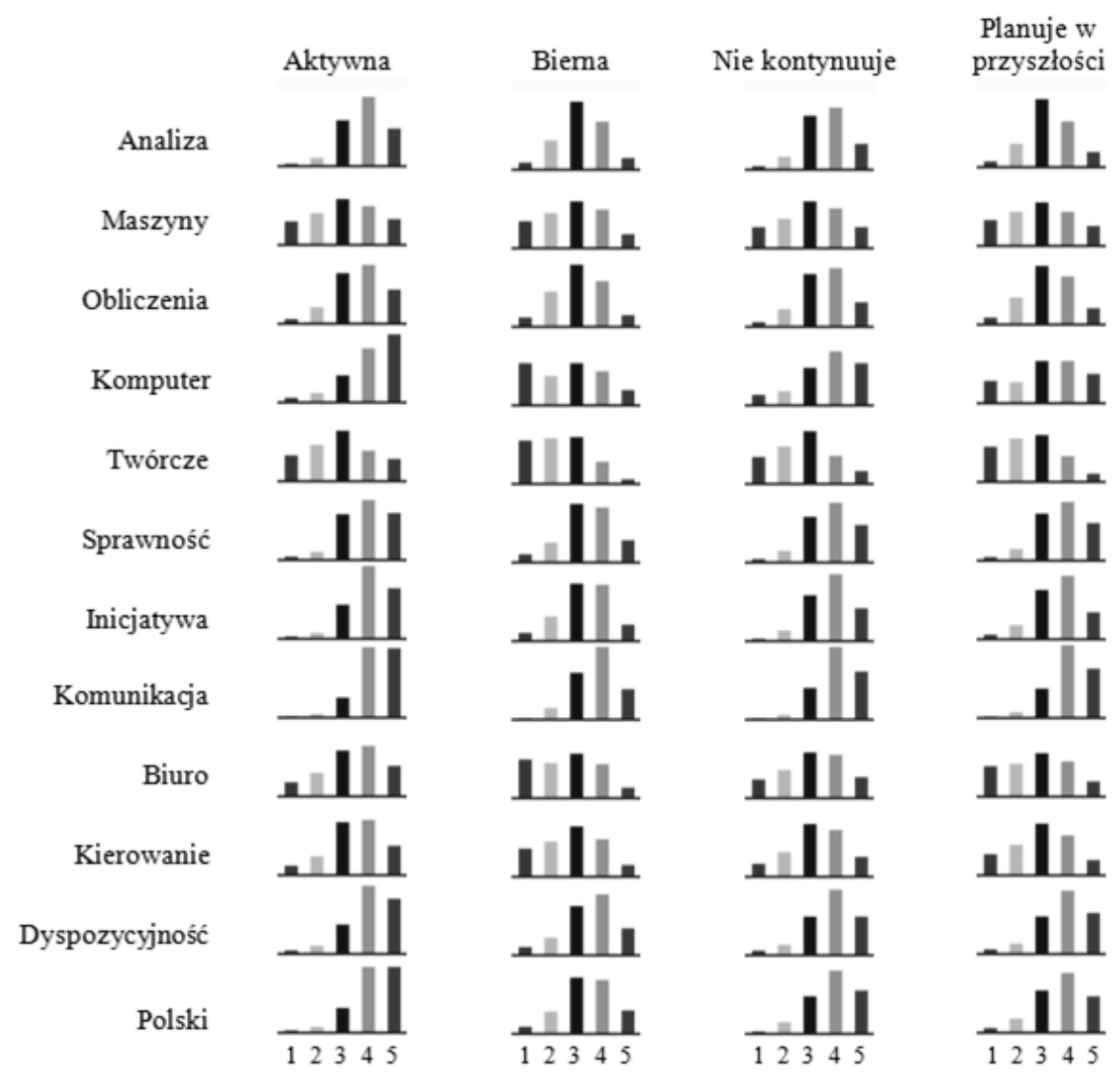

Źródło: opracowanie własne na podstawie danych Bilans Kapitału Ludzkiego - 2013. 
Tabela 1. Ocena powiązań pomiędzy deklarowanym poziomem kompetencji a przyjmowaną strategią edukacyjną.

\begin{tabular}{|l|c|c|c|}
\hline Kompetencje & $\begin{array}{c}\text { Statystyka } \\
\text { Chi-kwadrat }\end{array}$ & Wartość p & $\begin{array}{c}\text { Wspólczynnik } \\
\text { Cramera }\end{array}$ \\
\hline Komputer & 2700,758 & 0,000 & 0,226 \\
\hline Polski & 1473,211 & 0,000 & 0,167 \\
\hline Inicjatywa & 1327,102 & 0,000 & 0,159 \\
\hline Analiza & 1227,627 & 0,000 & 0,153 \\
\hline Komunikacja & 1091,061 & 0,000 & 0,144 \\
\hline Obliczenia & 813,329 & 0,000 & 0,124 \\
\hline Dyspozycyjność & 729,324 & 0,000 & 0,118 \\
\hline Sprawność & 718,586 & 0,000 & 0,117 \\
\hline Kierowanie & 728,475 & 0,000 & 0,117 \\
\hline Biuro & 684,856 & 0,000 & 0,114 \\
\hline Twórcze & 428,389 & 0,000 & 0,090 \\
\hline Maszyny & 117,729 & 0,000 & 0,047 \\
\hline
\end{tabular}

Źródło: obliczenia własne na podstawie danych Bilans Kapitału Ludzkiego - 2013

Ocena przeprowadzona na podstawie testu chi-kwadrat oraz wartości współczynnika V-Cramera niosą informację o związkach pomiędzy cechami będącymi przedmiotem rozważań, ale dotyczą wyłącznie par zmiennych typu kompetencjastrategia bez uwzględnienia potencjalnych interakcji pomiędzy ocenami różnych kompetencji, co do których można przypuszczać, że są ze sobą skorelowane.

Ponieważ pomiar kompetencji odbywał się na skali porząakowej, do oceny powiązań pomiędzy umiejętnościami zastosowano współczynniki korelacji Kendalla. Utworzone macierze korelacji przedstawiono na rys. 2 korzystając $\mathrm{z}$ metod wizualizacji technicznie dostępnych w pakiecie corrplot programu R. Natężenie koloru informuje o sile korelacji. Dodatkowo wykorzystano procedury aglomeracyjne do wyodrębnienia podzbiorów cech podobnych do siebie.

W rozpatrywanym zbiorze kompetencji nie występują korelacje ujemne. Najsilniejsze korelacje odnotowano pomiędzy zdolnościami kierowniczymi oraz organizacją pracy biurowej w każdej z analizowanych grup. Z kolei zdolności twórcze i umiejętność obsługi maszyn są słabo skorelowane ze wszystkimi pozostałymi kompetencjami, w klasyfikacji tworzą odrębne grupy. Grupowanie kompetencji, mimo pewnych różnic, przebiega według podobnych wzorców. Umiejętności komunikacyjne, biegłość językowa oraz organizowanie pracy i wykazywanie inicjatywy zawsze przynależą do jednej grupy. Dużym podobieństwem charakteryzuje się także samoocena umiejętności analitycznych, obsługi komputera oraz wykonywania obliczeń. 
Rys. 2. Wizualizacja macierzy korelacji Kendalla pomiędzy zmiennymi reprezentującymi dwanaście kompetencji
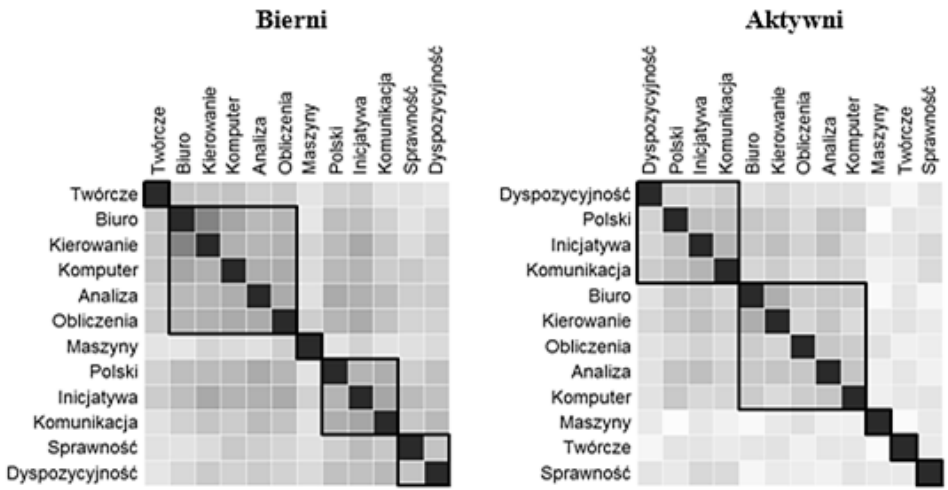

Deklarujący w przyszlości
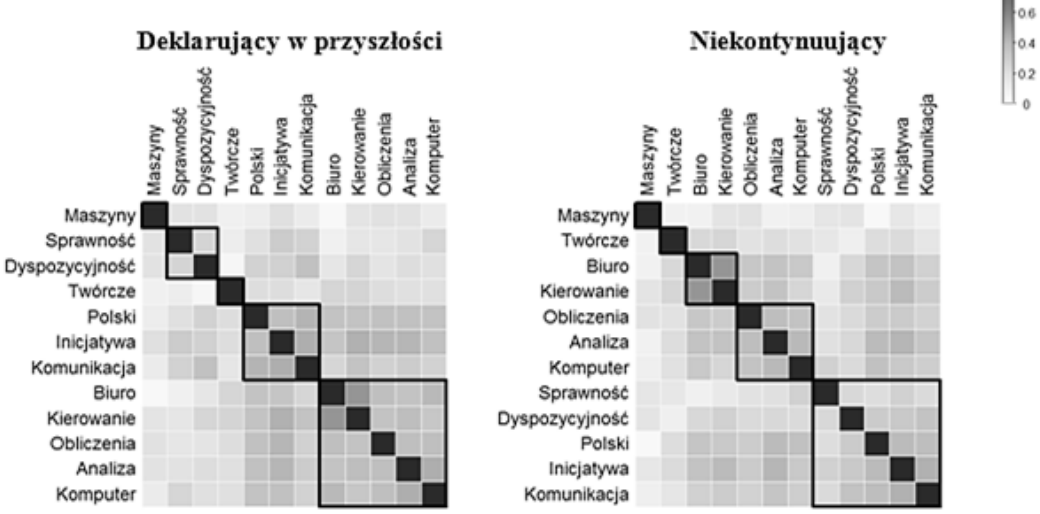

Źródło: opracowanie własne na podstawie danych Bilans Kapitału Ludzkiego - 2013.

Skorelowanie cech pozwala przypuszczać, że w celu uproszczenia opisu można dokonać redukcji wielowymiarowości przy zastosowaniu analizy głównych składowych, choć ze względu na specyfikę danych wyniki należy traktować z pewną ostrożnością. Ze względu na brak skorelowania $\mathrm{z}$ pozostałymi cechami $\mathrm{w}$ analizie pominięto umiejętności twórcze oraz związane z eksploatacją maszyn. Kierując się kryterium Kaisera oraz wykresem osypiska ${ }^{9}$ ustalono, że interpretację współwystępowania można przeprowadzić na podstawie dwóch pierwszych składowych, które reprezentują odpowiednio 50,2\% i 10,03\% zmienności. Składowe wyodrębniono na podstawie całego zbioru obserwacji, bez podziału na grupy. Następnie sporządzono wykresy typu biplot z wykorzystaniem pakietu BiplotGUI programu $\mathrm{R}^{10}$, na które naniesiono dwuwymiarowe wykresy gęstości odpowiadające poszczególnym strategiom edukacyjnym (rys. 3).

\footnotetext{
${ }^{9}$ A. Stanisz, op. cit., s. 175.

${ }^{10}$ A. La Grange, N. Le Roux, S. Gardner-Lubbe, BiplotGUI: Interactive Biplots in R, ,Journal of Statistical Software" 2009, 30(12), s. 1-37.
} 
Rys. 3. Wyniki analizy głównych składowych z uwzględnieniem strategii edukacyjnych

\section{Bierni}

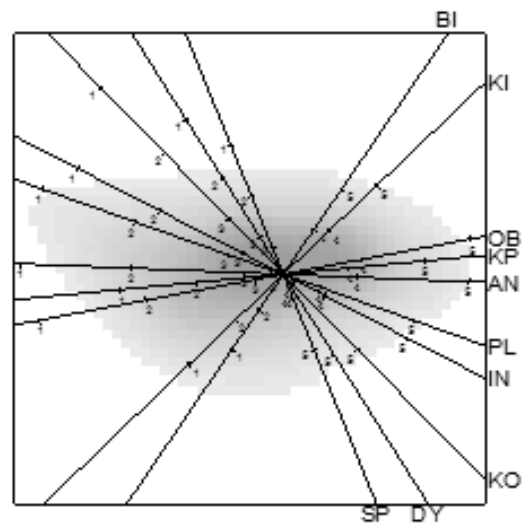

Deklarujący w przyszlości

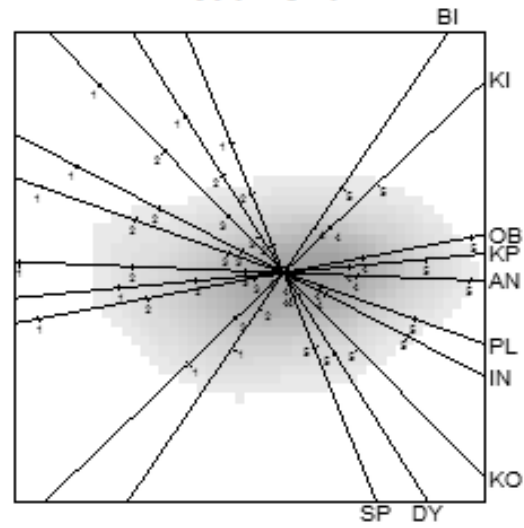

Aktywni

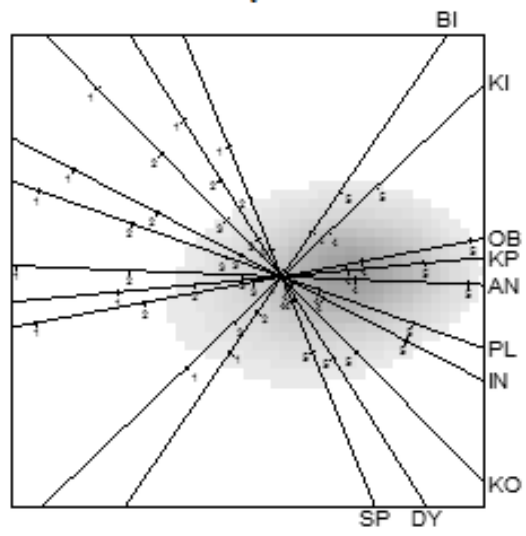

Niekontynuujący

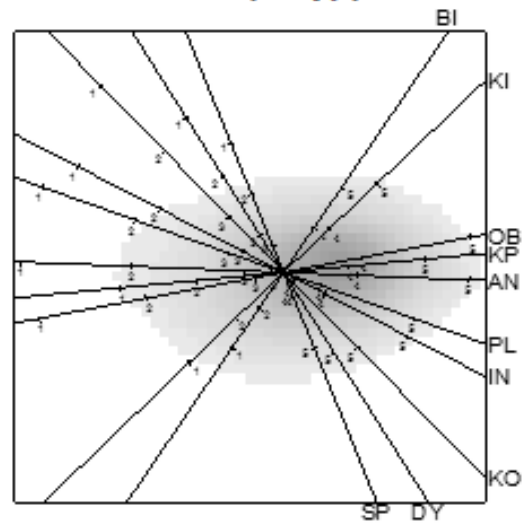

BI - Biuro, KI - Kierowanie, OB - Obliczenia, KP - Komputer, AN - Analiza, PL - Polski, IN - Inicjatywa, KO - Komunikacja, DY - Dyspozycyjność, SP - Sprawność

Źródło: opracowanie własne na podstawie danych Bilans Kapitału Ludzkiego - 2013.

Biploty przedstawione na rys. 3 wskazują, że osoby z grupy aktywnych edukacyjnie zdecydowanie wyżej oceniają swoje kompetencje od osób biernych i deklarujących chęć kształcenia się w przyszłości. Zaobserwowana prawidłowość dotyczy głównie zestawu czynników - kompetencji reprezentowanych przez pierwszą składową, do których zaliczyć należy: umiejętność wykonywania obliczeń, zdolności analityczne, umiejętności informatyczne, sprawne posługiwanie się językiem polskim oraz wykazywanie inicjatywy i samoorganizowanie pracy. Zwraca uwage rozciągnięcie wykresu gęstości w kierunku niskich ocen tych kompetencji w grupie respondentów biernych edukacyjnie. 


\section{Zakończenie}

Przeprowadzone analizy pozwalają na zweryfikowanie postawionych hipotez badawczych. Po pierwsze, istnieją statystycznie istotne związki o różnej sile pomiędzy deklarowanym poziomem kompetencji a przyjmowaną strategią edukacyjną. Po drugie, wyniki analizy opartej na podejściu wielowymiarowym sugerują istnienie zestawów umiejętności powiązanych z postawami edukacyjnymi. Interesującym wynikiem badań jest stwierdzenie prawidłowości polegającej na tym, że wysokiej samoocenie poziomu kompetencji towarzyszy zaangażowanie w uczenie się przez całe życie, natomiast wśród respondentów oceniających swe kompetencje nisko częściej występuje postawa bierna. Pozwala to na odniesienie się do trzeciej i czwartej hipotezy badawczej. Otrzymane rezultaty skłaniają do obalenia hipotezy trzeciej - osoby o niskim poziomie kompetencji to grupa w największym stopniu niezainteresowana ich rozwijaniem, a jej przedstawiciele rzadziej decydują się na uczestnictwo w kształceniu. Wyniki badania wskazują na prawdziwość hipotezy czwartej - osoby o wysokim poziomie kompetencji są świadome wartości, jakie niesie ich posiadanie, i dążą do dalszego ich podnoszenia. Komentując wyniki warto jeszcze raz zaakcentować, że przeprowadzone badanie opiera się na samoocenie kompetencji, czyli subiektywym ich postrzeganiu, a nie na zastosowaniu obiektywnych kryteriów, co może prowadzić do pewnych zniekształceń, niemniej jednak ujawnione prawidłowości wskazują na istnienie powiązań pomiędzy zasobami kompetencji a zachowaniami edukacyjnymi.

\section{Bibliografia}

Bilans kapitatu ludzkiego w Polsce. Badania ludności, 2013, http://bkl.parp.gov.pl/system/files/Downloads/20140527101857/BKL_ludnosc_2013.pdf?1401179482.

Dunteman G.H., Principal Components Analysis, Sage Publications, Newbury Park CA.

Gabriel K.R., The Biplot Graphic Display of Matrices with Application to Principal Component Analysis, „Biometrica” 1971, nr 58 (3), s. 453-467, doi: 10.1093/biom et/58.3.453.

Kompetencje Polaków a potrzeby polskiej gospodarki, Raport podsumowujący IV edycję badań BKL z 2013 r., red. J. Górniak, Polska Agencja Rozwoju Przedsiębiorczości, Warszawa 2014.

Górniak J., My i nasze pieniądze. Studium postaw wobec pieniądza, Wydawnictwo Aureus, Kraków 2000.

Grześkowiak A., Statystyczna analiza aktywności edukacyjnej osób dorostych w Polsce, „Ekonometria” 2013, 2 (40), s. 22-35.

Jolliffe I., Principal Component Analysis. Springer, New York 2002.

Kroonenberg P.M., Applied Multiway Data Analysis, John Wiley \& Sons, Hoboken 2008.

La Grange A., N. Le Roux, S. Gardner-Lubbe, BiplotGUI: interactive biplots in R, „Journal of Statistical Software" 2009, 30(12), s. 1-37. 
Uwarunkowania decyzji edukacyjnych, red. M. Rószkiewicz, K. Saczuk, Instytut Badań Edukacyjnych, Warszawa 2014.

Sagan A., Jeden obraz ukazuje więcej niż 10 liczb, czyli jak budować mapy zadowolenia klienta z wykorzystaniem programu STATISTICA, StatSoft, Kraków 2004.

Stanisz A., Przystępny kurs statystyki z zastosowaniem STATISTICA PL na przykladach z medycyny, StatSoft, Kraków 2007.

Strzelecki P., K. Saczuk, I. Grabowska, I.E. Kotowska, Rynek pracy [w:] Diagnoza Spoteczna 2013. Warunki i jakość życia Polaków, red. J. Czapiński, T. Panek, „Contemporary Economics” 2013, vol. 7, Special Issue. 